\title{
On the fauna of Psocoptera of Unguja (Zanzibar) Island (Tanzania, East Africa)
}

\author{
Dilian Georgiev
}

Department of Ecology and Environmental Conservation, University of Plovdiv, Tsar Assen Street 24, 4000 Plovdiv, Bulgaria, diliangeorgiev@gmail.com; https://orcid.org/0000-0003-2885-4895

\begin{abstract}
A total of 28 species of 13 families were registered. All species recorded were new records to the Zanzibar autonomous region, ten to Tanzania, eight to East Africa and two (Lepidopsocus pretiosus (Banks, 1942) and Belaphopsocus murphyi Lienhard, 1991) were new to the entire African continent. Original photos of 22 of the found species were provided, some of these species had never been photographed before.
\end{abstract}

Keywords: Africa, Insecta, new records, Psocoptera, Zanzibar

\section{Introduction}

The fauna of Psocoptera of the equatorial and tropical Africa is poorly studied. Some areas, such as Angola, South Africa, Kenya, Tanzania and Madagascar, have been studied and many new species have been described. However, extremely many white spots remain with an unclear species composition of Psocoptera from the region. One such unexplored area is the island of Unguja, part of the Zanzibar autonomous region of Tanzania. The only known psocid record from this area is of Psocidus zanzibarensis Pearman, 1934, a species described by a single specimen collected (Pearman, 1934). My aim was to contribute to the knowledge of the fauna of Psocoptera of this area and to the biodiversity in general, providing data for more conservation activities of the unique nature of the island.

\section{Material and methods}

All the material was collected from two areas of the east coast of the Unguja Island - north part of the Michamwi Peninsula (many closely situated spots) and at the entrance of the Kuza Cave near the Jambiani Village (Figs 1, 2). Three main habitats were surveyed: mangroves, dry coastal scrubland (Michamwi) and a patch of wet tropical forest (Kuza Cave). The species were identified according to identification keys in monographs or original descriptions (Badonnel, 1955; Broadhead, 1955; Thornton et al., 1972; Broadhead \& Richards 1980, 1982; Lienhard, 1991, 1998 and other). Distributional data and taxonomy order followed Lienhard (2016).

\section{Results}

A total of 28 species of 13 families were registered. All species recorded were new records to the Zanzibar autonomous region, ten to Tanzania, eight to East Africa and two to the entire African continent. Original pictures of 22 of the found species, some of which had never been photographed before, were provided in Fig. 3.

Lepidopsocidae

Thylacella angustipennis Broadhead \& Richards, 1982 (Fig. 3 A)

Material examined: Michamwi Peninsula: 5.3.2021, sandy coastal area with scrubs, from a pile of old palm leaf mats, S06 07 55.5 E39 29 31.2, 6 m a.s.1., 1 ô, 1 우, 


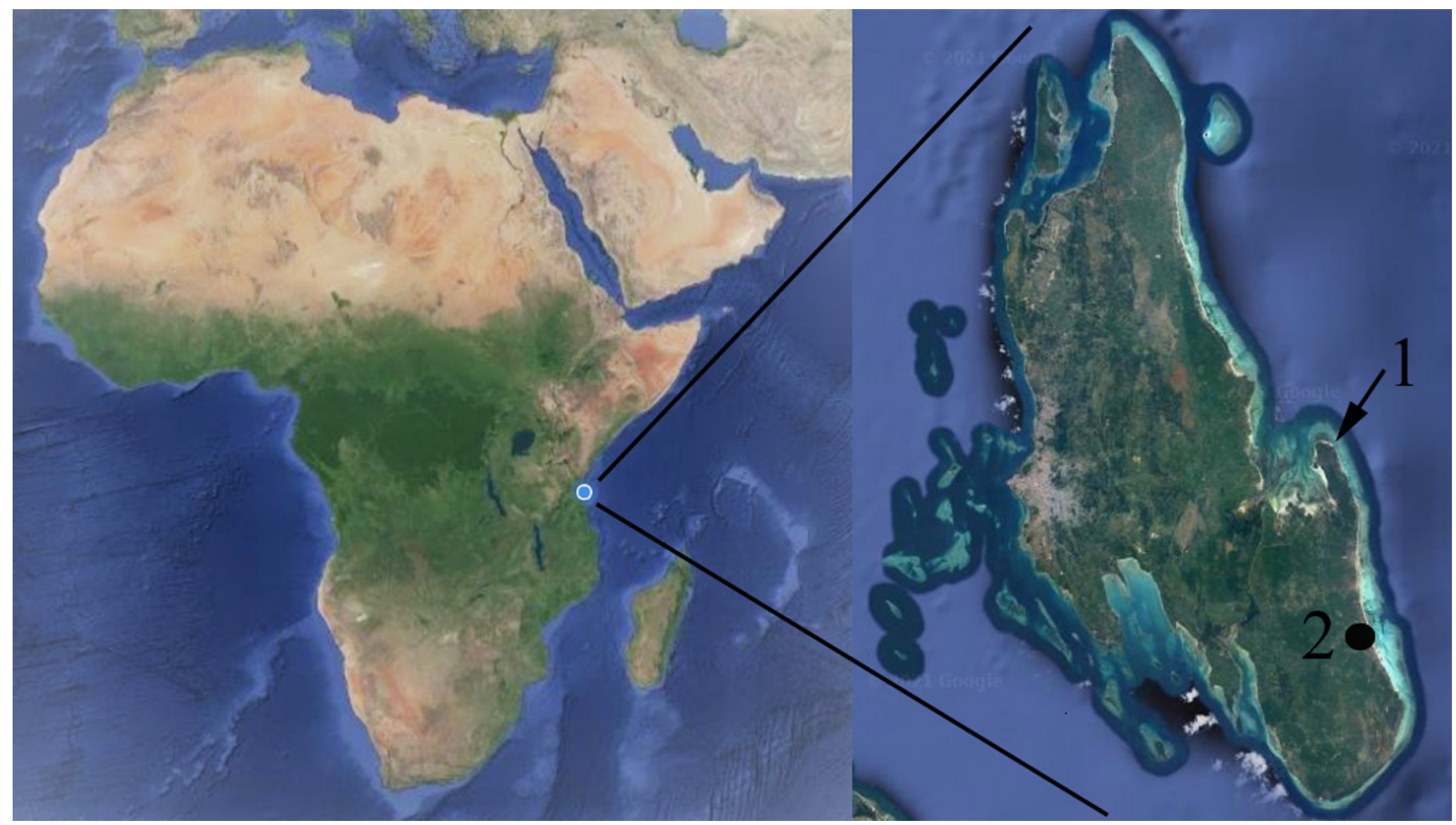

Fig. 1. Location map of the study area: 1 - the north part of the Michamwi Peninsula, 2 - at the entrance of the Kuza Cave, near the Jambiani Village.

collected by beating over white plastic container. Remarks: The species has been previously known only from its type locality in Kenya from a female specimen (Broadhead \& Richards, 1982). The male, which has been found during the present study, is similar in colour with the female but its wings are a little bit more pointed and longer in comparison to the body. New record for Tanzania.

\section{Echmepteryx madagascariensis (Kolbe, 1885) (Fig. 3} B)

Material examined: Michamwi Peninsula: 28.2.2021, yard of a hotel, on a trunk of Panadanus sp., S06 08 25.9 E39 29 26.4, $3 \mathrm{~m}$ a.s.1., 2 우, collected during night with a head torch by hand and a brush; same date, yard of a hotel, among Cocos nucifera and Panadanus sp., from fallen nests of Ploceus subaureus, S06 08 30.5 E39 29 23.5, 5 m a.s.1., 3 우, collected by beating over white plastic container; same date, coastal area with bushes and palms, from dry leaves of Cocos nucifera, S06 0844.1 E39 29 21.2, 14 m a.s.1., 3 우우, collected by beating the vegetation; 3.3.2021, bushes near mangroves, from dry leaves of Cocos nucifera, S06 08 39.1 E39 29 35.6, 7 m a.s.1., 2 우, collected by beating the vegetation; 5.3.2021, sandy coastal area with scrubs, from a pile of old palm leaf mats, S06 0755.5 E39 $2931.2,6$ m a.s.l., 2 万ิ $0^{\lambda}, 8$ q 9 , collected by beating over white plastic container; 6.3.2021, sandy coastal area with scrubs, from a pile of old palm leaf mats, S06 0755.5 E39 29 31.2, 6 m a.s.1., 1 o , 3 우, 1 nymph, collected by beating over white plastic container; at the entrance of the Kuza Cave, near the Jambiani Village: 5.3.2021, wet forest at the cave entrance, from dry brunches with dry leaves, S06 18 14.5 E39 32 $00.9,25 \mathrm{~m}$ a.s.1., 2 9 , collected by beating the vegetation. Remarks: Widespread species in the Tropics. New record for the Zanzibar autonomous region.

\section{Echmepteryx pallida Smithers, 1965 (Fig. 3 D)}

Material examined: At the entrance of the Kuza Cave, near the Jambiani Village: 5.3.2021, wet forest at the cave entrance, from dry brunches with dry leaves, S06 1814.5 E39 32 00.9, $25 \mathrm{~m}$ a.s.1., 3 우, collected by beating the vegetation. Remarks: The species is known 
On the fauna of Psocoptera of Unguja (Zanzibar) Island (Tanzania, East Africa)
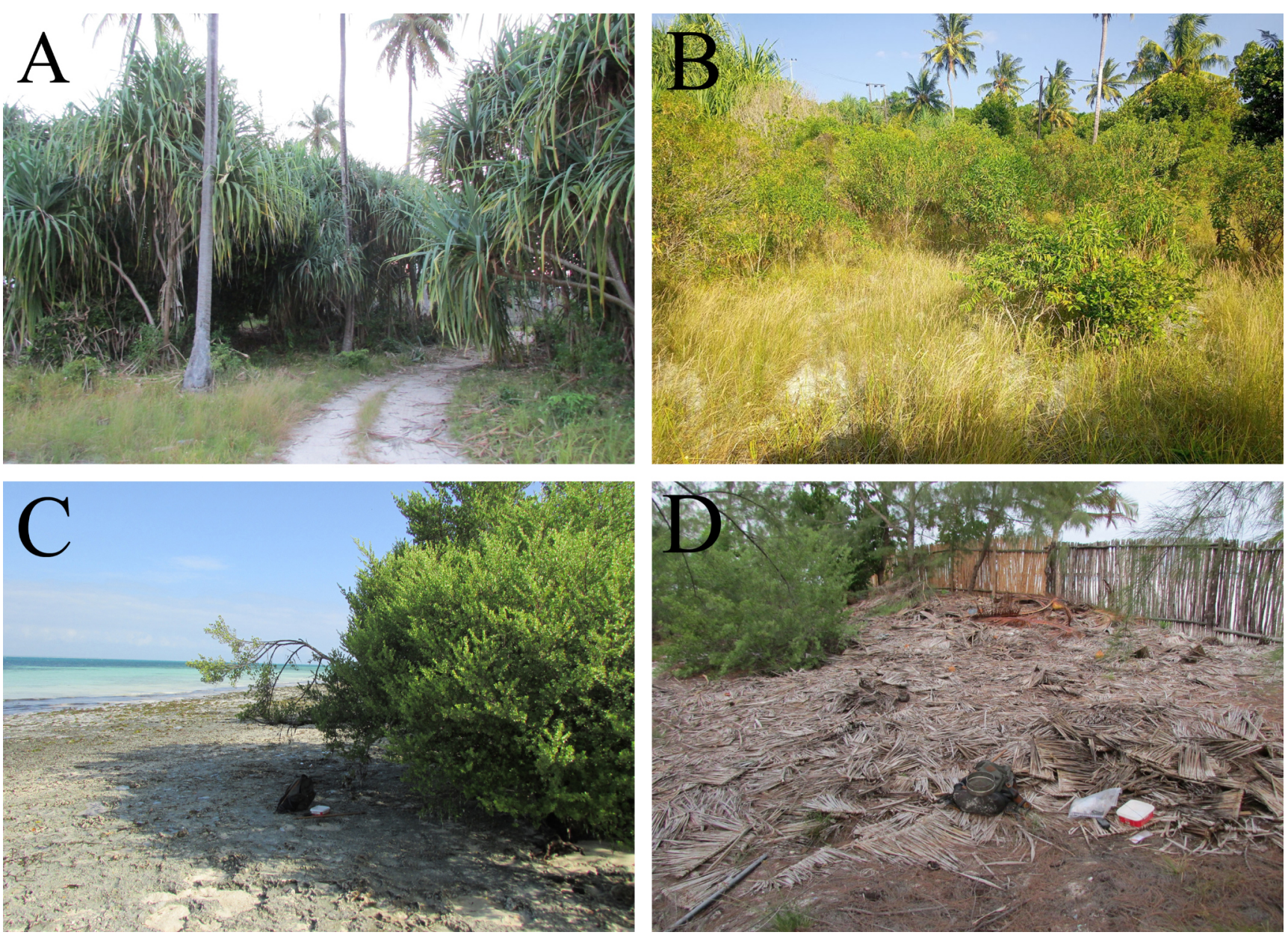

Fig. 2. Some of the surveyed habitats of Psocoptera: (A) a patch of Panadanus sp. (S06 0828.5 E39 29 35.0), locality of Echmepteryx lunulata, Pachytroctes cf. bicoloripes, Belaphopsocus murphyi; (B) dry coastal scrubland (S06 08 20.8 E39 29 28.8), locality of Mepleres maculatus, Peripsocus keniensis, Ectopsocus spp., Trichopsocus coloratus, Lepolepis bicolor, B. murphyi and other; (C) bushes at the tidal zone (S06 0739.4 E39 29 28.2), locality of Archipsocus textor and P. keniensis; (D) sandy coastal area with scrubs, a pile of old palm leaf mats (S06 0755.5 E39 29 31.2), locality of Thylacella angustipennis, Echmepteryx madagascariensis, Liposcelis albothoracica, L. paetula and L. annulata.

from Australia, Indonesia, Christmas Island, Polynesia and Equatorial Guinea in Africa. New record for East Africa.

Echmepteryx lunulata Thornton, Lee \& Chui, 1972 (Fig. 3 C)

Material examined: Michamwi Peninsula: 1.3.2021, scattered bushes and trees, in a patch of Panadanus sp., from dry leaves of same plant, S06 08 28.5 E39 29 35.0, 6 m a.s.1., 1 J, 1 \%, 1 nymph, collected by beating the vegetation; at the entrance of the Kuza Cave, near the Jambiani Village: 5.3.2021, wet forest at the cave entrance, from dry brunches with dry leaves, S06 18 14.5 E39 32 00.9, 25 m a.s.1., 2 q , collected by beating the vegetation. Remarks: The species is known from the Antilles, Equatorial Guinea, Chagos Archipelago, Reunion, Christmas Island, Indonesia, Japan, Galapagos, Hawaii, Melanesia, Micronesia. New record for East Africa.

\section{Lepidopsocus pretiosus (Banks, 1942) (Fig. 3 E)}

Material examined: Michamwi Peninsula: 28.2.2021, yard of a hotel, on a trunk of Panadanus sp., S06 08 25.9 E39 29 26.4, $3 \mathrm{~m}$ a.s.1., 2 q , collected during 


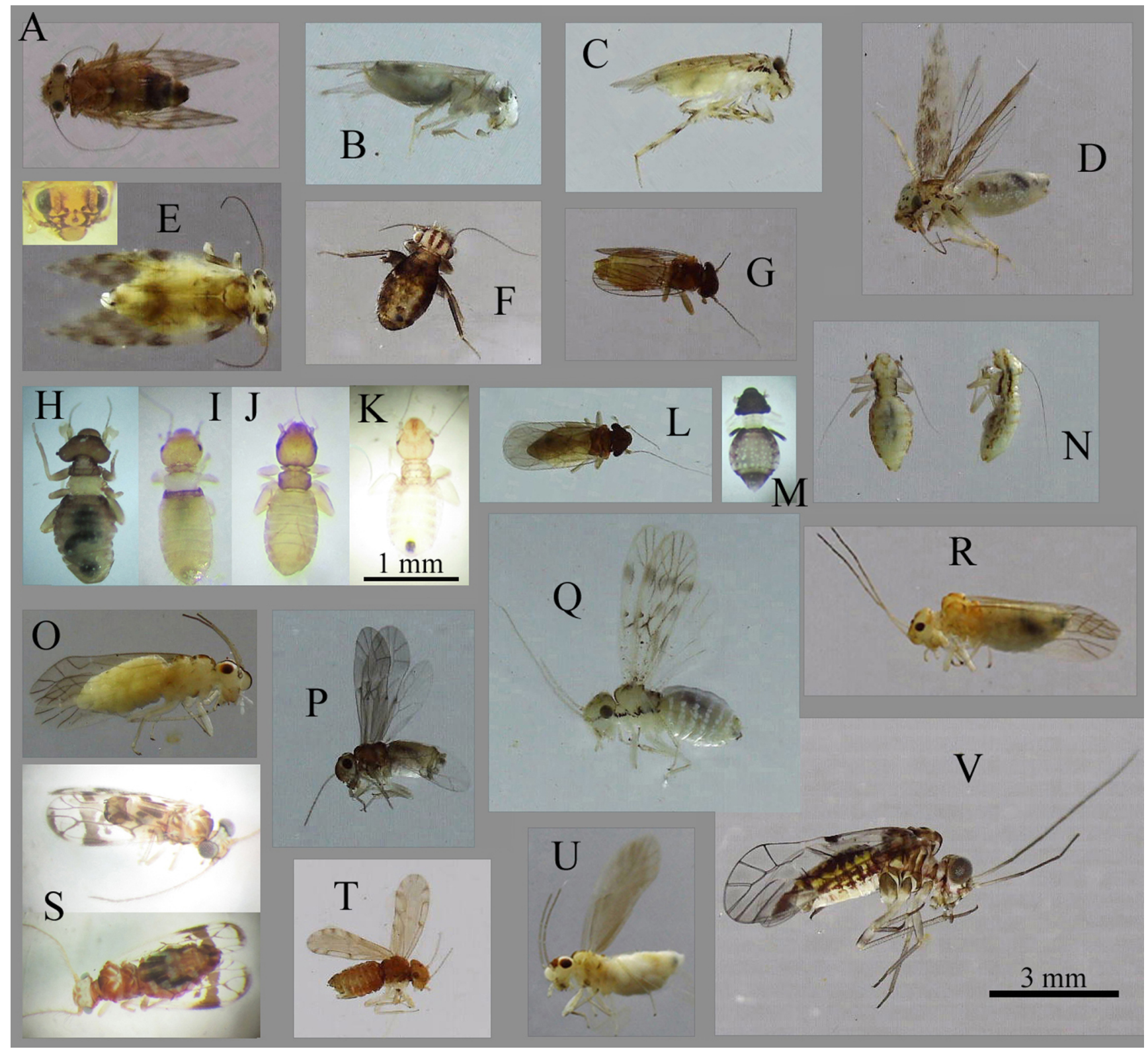

Fig. 3. External views of some of the species recorded: (A) Thylacella angustipennis $\bigcirc$, (B) Echmepteryx madagascarensis $\bigcirc^{\text {, }}$

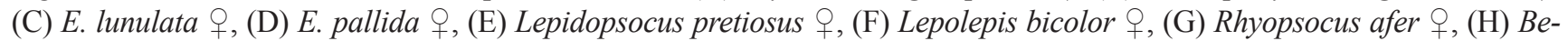

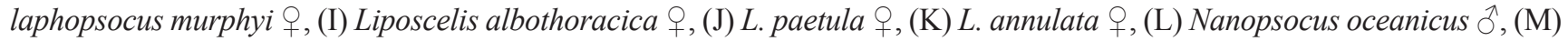
Pachytroctes cf. bicoloripes + , (N) Tapinella curvata $\odot$, (O) Stenocaecilius gilvus $\odot$, (P) Peripsocus keniensis $q$, (Q) Tricho-

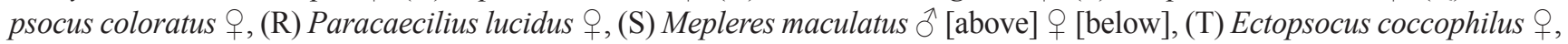

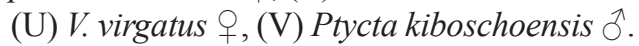

night with a head torch by hand and a brush. Remarks: The species is known from Guam, Micronesia, Christmas Island, Indonesia, Melanesia and Polynesia. The morphology of the collected specimens agree with the redescription of Thornton et al. (1972). The specific head pattern of this species is shown in Fig. 3 E. New record for Africa.

\section{Lepolepis bicolor Broadhead, 1955 (Fig. 3 F)}

Material examined: Michamwi Peninsula: 27.2.2021, coastal area with bushes and palms, from dry leaves of Cocos nucifera on the ground, S06 0844.3 E39 29 21.1, $4 \mathrm{~m}$ a.s.l., 1 q , collected by beating over white plastic container; 2.3.2021, scattered bushes and trees, brunches 
of bushes and trees, S06 0820.8 E39 29 28.8, 3 m a.s.l., 1 , collected by beating the vegetation. Remarks: The species is known from Great Britain, Iles Glorieuses, Reunion and India. New record for Tanzania.

\section{Trogiidae}

\section{Trogium pulsatorium (Linnaeus, 1758)}

Material examined: Michamwi Peninsula: 28.2.2021, coastal area with bushes and palms, from grass of Poaceae, S06 0844.1 E39 29 21.2, 14 m a.s.1., 8 o , , collected by sweep netting. Remarks: Widespread species. New record for the Zanzibar autonomous region.

\section{Psoquillidae}

Rhyopsocus afer (Badonnel, 1948) (Fig. 3 G)

Material examined: Michamwi Peninsula: 28.2.2021, yard of a hotel, among Cocos nucifera and Panadanus sp., from fallen nest of Ploceus subaureus, S06 0830.5 E39 29 23.5, $5 \mathrm{~m}$ a.s.1., 1 + , collected by beating over white plastic container. Remarks: The species is known from Congo, Angola, Equatorial Guinea, Ivory Coast, South Africa, Tanzania and India. New record for the Zanzibar autonomous region.

\section{Liposcelididae}

\section{Liposcelis albothoracica Broadhead, 1955 (Fig. 3 I)}

Material examined: Michamwi Peninsula: 28.2.2021, yard of a hotel, among Cocos nucifera and Panadanus sp., from a fallen nest of the golden weaver (Ploceus subaureus), S06 08 30.5 E3929 23.5, 5 m a.s.1., 1 +, collected by beating over white plastic container; same date, coastal area with bushes and palms, from dry leaves of Cocos nucifera, S06 08 44.1 E39 29 21.2, 14 m a.s.1., 1 , collected by beating the vegetation; 2.3.2021, scattered bushes and trees, brunches of bushes and trees, S06 0820.8 E39 29 28.8, 3 m a.s.1., 1 क , collected by beating the vegetation; 4.3.2021, scattered bushes and trees, small nest fallen on the ground, S06 08 18.7 E39 29 38.6, $4 \mathrm{~m}$ a.s.l., 1 \% , collected by beating over white plastic container; 5.3.2021, sandy coastal area with scrubs, from a pile of old palm leaf mats, S06 0755.5
E39 29 31.2, 6 m a.s.1., 1 क, collected by beating over white plastic container. Remarks: The species was described from Great Britain as translocated (in Turkey millet seed in ship's hold). Later, it was found in West Africa (Cape Verde Islands and Senegal) and Mexico. New record for East Africa.

\section{Liposcelis annulata Badonnel, 1955 (Fig. 3 K)}

Material examined: Michamwi Peninsula: 5.3.2021, sandy coastal area with scrubs, from a pile of old palm leaf mats, S06 0755.5 E39 29 31.2, 6 m a.s.1., 5 우우, collected by beating over white plastic container; 6.3.2021, same locality and methods, 1 O , 4 우. Remarks: The species has been previously known from Angola and Kenya. New record for Tanzania.

\section{Liposcelis bostrychophila Badonnel, 1931}

Material examined: Michamwi Peninsula: 28.2.2021, yard of a hotel, from a trunk of Panadanus sp., S06 08 25.9 E39 29 26.4, 3 m a.s.1., 1 q, collected by beating the vegetation; same date, coastal area with bushes and palms, from dry leaves of Cocos nucifera, S06 0844.1 E39 29 21.2, $14 \mathrm{~m}$ a.s.1., 1 \% , collected by beating the vegetation; 6.3.2021, yard of a hotel, among Cocos nucifera and Panadanus sp., from a fallen nest of the golden weaver, S06 0830.5 E39 29 23.5, 5 m a.s.1., 1 , collected by beating over white plastic container; same date, sandy coastal area with scrubs, from a pile of old palm leaf mats, S06 0755.5 E39 29 31.2, 6 m a.s.l., 2 우, collected by beating over white plastic container. Remarks: Widespread species. New record for Tanzania.

\section{Liposcelis paetula Broadhead, 1950 (Fig. 3 J)}

Material examined: Michamwi Peninsula: 27.2.2021, coastal area with bushes and palms, from dry leaves and grasses on the ground, S06 0844.3 E39 29 21.1, 4 $\mathrm{m}$ a.s.1., 2 + $\odot$, collected by sieving; 5.3.2021, sandy coastal area with scrubs, from a pile of old palm leaf mats, S06 0755.5 E39 29 31.2, 6 m a.s.1., 1 \%, collected by beating over white plastic container. Remarks: The species has been previously known from Great Britain, Italy, Canary and Cape Verde Islands and Madeira. The specimens collected on the Unguja Island are darker in colour as compared to these mentioned by Lienhard (1998) from the Canary Islands. New record for East Africa. 
Belaphopsocus murphyi Lienhard, 1991 (Fig. 3 H)

Material examined: Michamwi Peninsula: 1.3.2021, scattered bushes and trees, a patch of Panadanus sp., from dry leaves, S06 0828.5 E39 29 35.0, 6 m a.s.l., 1 $q$, collected by beating over white plastic container; 2.3.2021, scattered bushes and trees, brunches of bushes and trees, S06 0820.8 E39 29 28.8, 3 m a.s.1., 1 $q$, collected by beating the vegetation. Remarks: This species has been previously known only from its type locality in Singapore. The morphology of the two female specimens collected during the present study fits with the original description of Lienhard (1991) (Fig. 3 $\mathrm{H})$. New record for Africa and second record of this species.

\section{Pachytroctidae}

Nanopsocus oceanicus Pearman, 1928 (Fig. 3 L)

Material examined: Michamwi Peninsula: 28.2.2021, yard of a hotel, among Cocos nucifera and Panadanus sp., from a fallen nest of the golden weaver, S06 08 30.5 E39 29 23.5, $5 \mathrm{~m}$ a.s.1., 1 ô, collected by beating over white plastic container. Remarks: Widespread warm loving species. New record for Tanzania.

Pachytroctes cf. bicoloripes Badonnel, 1949 (Fig. 3 M)

Material examined: Michamwi Peninsula: 1.3.2021, scattered bushes and trees, a patch of Panadanus sp., from dry leaves, S06 0828.5 E39 29 35.0, 6 m a.s.l., 1 , collected by beating the vegetation; at the entrance of the Kuza Cave, near the Jambiani Village: 5.3.2021, wet forest at the cave entrance, from dry brunches with dry leaves, S06 1814.5 E39 32 00.9, 25 m a.s.1., 8 우, collected by beating the vegetation. Remarks: The morphology of the specimens collected from Unguja has some similarities with that of $P$. bicoloripes mentioned by Badonnel (1955). The species $P$. bicoloripes has been previously known from the Ivory Coast, Angola, Senegal and India. New record of this genus and family for Tanzania.

\section{Tapinella curvata Badonnel, 1949 (Fig. 3 N)}

Material examined: Michamwi Peninsula: 1.3.2021, scattered bushes and trees, dry brunches with leaves of a broad leaf tree, S06 0829.1 E39 29 33.4, 8 m a.s.1., 1 , collected by beating the vegetation. Remarks: Known from West Africa (Congo, Angola, Nigeria and Senegal) and the United Arabian Emirates. New record for East Africa.

Caeciliusidae

Stenocaecilius gilvus (Pearman, 1932) (Fig. 3 O)

Material examined: Michamwi Peninsula: 27.2.2021, coastal area with bushes and palms, from dry leaves of Cocos nucifera, S06 0844.3 E39 29 21.1, 4 m a.s.1., 1 q, collected by beating the vegetation. Remarks: The species has been previously known only from its type locality in Kenya. New record for Tanzania.

Valenzuela virgatus (Broadhead \& Richards, 1982)

(Fig. $3 \mathrm{U}$ )

Material examined: Michamwi Peninsula: 27.2.2021, coastal area with bushes and palms, from dry leaves of Cocos nucifera, S06 0844.3 E39 29 21.1, 4 m a.s.1., 1 $\uparrow$, collected by beating the vegetation. Remarks: The species has been previously known from continental Kenya and Tanzania. New record for the Zanzibar autonomous region.

Paracaecilius lucidus Broadhead \& Richards, 1982

(Fig. 3 R)

Material examined: Michamwi Peninsula: 28.2.2021, coastal area with bushes and palms, from grass of Poaceae, S06 08 44.1 E39 29 21.2, 14 m a.s.l., 1 + , collected by sweep netting. Remarks: The species has been previously known only from its type locality in Kenya. New record for Tanzania.

\section{Peripsocidae}

Peripsocus keniensis Broadhead \& Richards, 1980 (Fig. 3 P)

Material examined: Michamwi Peninsula: 2.3.2021, scattered bushes and trees, brunches of bushes and trees, S06 0820.8 E39 29 28.8, 3 m a.s.1., 2 우, collected by beating the vegetation; same date, bushes at the periphery of the tidal zone, from brunches of bushes, 
S06 07 39.4 E39 29 28.2, 2 m a.s.1., 2 우, collected by beating the vegetation; 3.3.2021, bush area on a limestone hill, from brunches of bushes and trees, S06 08 10.2 E39 2940.3 , 33 m a.s.1., 1 \% , collected by beating the vegetation; 4.3.2021, bushes and trees at the tidal zone, brunches of bushes and trees, S06 07 58.5 E39 29 34.3, $8 \mathrm{~m}$ a.s.1., 1 क , collected by beating the vegetation. Remarks: The species has been previously known only from its type locality in Kenya. New record for Tanzania.

\section{Ectopsocidae}

\section{Ectopsocopsis spathulata (Ball, 1943)}

Material examined: Michamwi Peninsula: 4.3.2021, bushes and trees at the tidal zone, brunches of bushes and trees, S06 0758.5 E39 29 34.3, 8 m a.s.1., 1 \&, collected by beating the vegetation. Remarks: The species has been previously known only from its type locality in Congo. New record for East Africa.

\section{Ectopsocus coccophilus Ball, 1943 (Fig. 3 T)}

Material examined: Michamwi Peninsula: 2.3.2021, scattered bushes and trees, brunches of bushes and trees, S06 0820.8 E39 29 28.8, 3 m a.s.1., 7 우, collected by beating the vegetation; 3.3.2021, bushes near mangroves, brunches of bushes, S06 0839.1 E39 29 35.6, $7 \mathrm{~m}$ a.s.l., 1 + , collected by beating the vegetation; 4.3.2021, bushes and trees at the tidal zone, dry brunches with dry leaves, S06 07 58.5 E39 29 34.3, 8 m a.s.l., 1 O , 2 q 9 , collected by beating the vegetation; 6.3.2021, yard of a hotel, among Cocos nucifera and Panadanus sp., from a fallen nest of Ploceus subaureus, S06 0830.5 E39 29 23.5, 57 m a.s.1., 1 , collected by beating the vegetation; at the entrance of the Kuza Cave, near the Jambiani Village: 5.3.2021, wet forest at the cave entrance, from dry brunches with

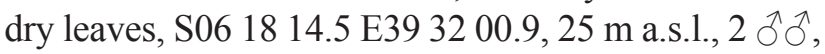
24 우, collected by beating the vegetation. Remarks: The species has been previously known from Congo and Indonesia only on the base of females. Males were collected for the first time during the present study. Their coloration and size did not differ significantly from these of the females. The little difference was that the males had longer wings compared to the body length. New record for East Africa.
Ectopsocus longisetosus Broadhead \& Richards, 1980

Material examined: Michamwi Peninsula: 2.3.2021, scattered bushes and trees, brunches of bushes and trees, S06 0820.8 E39 29 28.8, 3 m a.s.l., 2 q , , collected by beating the vegetation; 3.3.2021, bush area on a limestone hill, from brunches of bushes and trees, S06 08 10.2 E39 29 40.3, 33 m a.s.1., 1 + , collected by beating the vegetation; 4.3.2021, bushes and trees at the tidal zone, brunches of bushes and trees, S06 0758.5 E39 29 34.3, 8 m a.s.l., 3 ỗ, 3 우, collected by beating the vegetation; at the entrance of the Kuza Cave, near the Jambiani Village: 5.3.2021, wet forest at the cave entrance, from dry brunches with dry leaves, S06 1814.5 E39 32 00.9, 25 m a.s.1., 2, collected by beating the vegetation. Remarks: The species has been previously known only from continental Tanzania. New record for the Zanzibar autonomous region.

\section{Trichopsocidae}

Trichopsocus coloratus Lienhard, 1983 (Fig. 3 Q)

Material examined: Michamwi Peninsula: 2.3.2021, scattered bushes and trees, from brunches of bushes and trees, S06 0820.8 E39 29 28.8, 3 m a.s.1., 6 우, collected by beating the vegetation; 3.3.2021, bush area on a limestone hill, from brunches of bushes and trees, S06 08 10.2 E39 29 40.3, 33 m a.s.1., 1 ㅇ, collected by beating the vegetation; 4.3.2021, bushes and trees at the tidal zone, brunches of bushes and trees, S06 07 58.5 E39 29 34.3, 8 m a.s.1., 1 9, collected by beating the vegetation. Remarks: Till now the species has been previously known only from its type locality, Madeira Island. New record for East Africa.

\section{Archipsocidae \\ Archipsocus textor Enderlein, 1911}

Material examined: Michamwi Peninsula: 2.3.2021, bushes at the periphery of the tidal zone, from brunches of bushes, S06 0739.4 E39 29 28.2, 2 m a.s.l., 1 \%, collected by beating the vegetation. Remarks: The species has been previously known from continental Tanzania and Guinea. New record for the Zanzibar autonomous region. 
Elipsocidae

Elipsocidae sp.

Material examined: Michamwi Peninsula: 28.2.2021, coastal area with bushes and palms, from Poaceae grasses, S06 08 44.1 E39 29 21.2, 14 m a.s.1., 1 nymph, collected by sweep netting. Remarks: The specimen collected is entirely brown, resembling the coloration of Elipsocus ignobilis Broadhead \& Richards, 1982 known from continental Tanzania. The greyish-blue colour of its eyes also resembles the species mentioned. New record of this family for the Zanzibar autonomous region.

\section{Pseudocaeciliidae}

Mepleres maculatus (Broadhead \& Richards, 1982)

(Fig. $3 \mathrm{~S}$ )

Material examined: Michamwi Peninsula: 2.3.2021, scattered bushes and trees, from brunches of bushes and trees, S06 0820.8 E39 29 28.8, 3 m a.s.1., 1 o, 3 9 , , collected by beating the vegetation Remarks: The species has been previously known only from its type locality in Kenya. It was described by macerated specimens long time preserved in ethanol, so the authors, Broadhead \& Richards (1982), did not have the opportunity to describe the head coloration, having specific pattern (Fig. $3 \mathrm{~S}$ ). New record for Tanzania.

\section{Psocidae}

Ptycta kiboschoensis (Enderlein, 1907) (Fig. 3 V)

Material examined: Michamwi Peninsula: 28.2.2021, yard of a hotel, on a trunk of Panadanus sp., S06 08

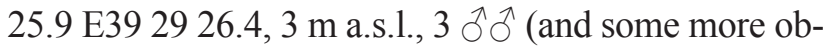
served, staying in a cluster on the bark), 3 우, collected by hand and a brush during night with a head torch. Remarks: The species has been previously known only from its type locality in continental Tanzania. New record for the Zanzibar autonomous region.

\section{References}

Badonnel A. 1955 Psocopteres de I'Angola. Publicações culturais da Companhia de Diamantes de Angola 26: 1-267.

Broadhead E. 1955 Two new psocid species from stored products in Britain. Proceedings of the Royal Entomological Society of London (B) 24 (1/2): 7-12.

Broadhead E., Richards A. 1980 The Peripsocidae and Psocidae (Psocoptera) of East Africa. Systematic Entomology 5: 357-397.

Broadhead E., Richards A. 1982 The Psocoptera of East Africa - a taxonomic and ecological survey. Biological Journal of the Linnean Society 17: 137-216.

Lienhard C. 1991 New records and species of Belaphopsocus (Psocoptera: Liposcelididae). Raffles Bulletin of Zoology 39 (1): 75-85.

Lienhard C. 1998 Psocoptères euro-méditerranées. Faune de France 83: 1-517.

Lienhard C. 2016 Country checklists of the Psocoptera species of the World, extracted from Lienhard C., Smithers, C. 2002 "Psocoptera (Insecta) - World catalogue and bibliography". Psocid News Special Issue I: 1-123.

Pearman J. 1934 New and little known African Psocoptera. Stylops 3 (6):121-132.

Thornton I., Lee S., Chui V. 1972 Insects of Micronesia: Psocoptera. Insects of Micronesia 8 (4): 45-144. 